\title{
Perceptions About The ISO 9000 (2000) Quality System Standard Revision And Its Value: The Dutch Experience
}

\author{
T. van der Wiele, J. van Iwaarden, R. Williams and B. Dale
}

\begin{tabular}{|l|l|}
\hline \multicolumn{2}{|l|}{ ERIM REPORT SERIES RESEARCH IN MANAGEMENT } \\
\hline ERIM Report Series reference number & ERS-2004-081-ORG (Organizational behavior and HRM) \\
\hline Publication & September 2004 \\
\hline Number of pages & 36 \\
\hline Email address corresponding author & vanderwiele@few.eur.nl \\
\hline Address & Erasmus Research Institute of Management (ERIM) \\
& Rotterdam School of Management / Rotterdam School of Economics \\
& Erasmus Universiteit Rotterdam \\
& P.O.Box 1738 \\
& 3000 DR Rotterdam, The Netherlands \\
& Phone: +31 10 408 1182 \\
& Fax: $\quad+31104089640$ \\
& Email: info@erim.eur.nl \\
& Internet: $\quad$ www.erim.eur.nl \\
\hline
\end{tabular}

Bibliographic data and classifications of all the ERIM reports are also available on the ERIM website: www.erim.eur.nl 


\section{ERASMUS RESEARCH INSTITUTE OF MANAGEMENT}

REPORT SERIES

\section{RESEARCH IN MANAGEMENT}

\begin{tabular}{|c|c|c|}
\hline \multicolumn{3}{|c|}{ BIBLIOGRAPHIC DATA AND CLASSIFICATIONS } \\
\hline Abstract & \multicolumn{2}{|c|}{$\begin{array}{l}\text { The aim of the research reported in this paper is to assess the relative value of the } 2000 \text { version } \\
\text { of the ISO } 9000 \text { series of quality management system standards in comparison to the } 1994 \\
\text { version. } 773 \text { organisations in the Netherlands which have all been certified to the ISO } 9000 \\
\text { standard were surveyed (a response rate of } 21.4 \% \text { ) and of these only } 22 \text { had not yet converted } \\
\text { to the } 2000 \text { version of the standard. Amongst the major findings are an overall positive } \\
\text { perception of the value of the ISO } 9000 \text { (2000) quality system standard and a consistently higher } \\
\text { appreciation of the } 2000 \text { version compared to the } 1994 \text { version. }\end{array}$} \\
\hline \multirow{3}{*}{$\begin{array}{l}\text { Library of Congress } \\
\text { Classification } \\
(\text { LCC) } \\
\text { Website LCC } \\
\end{array}$} & \multicolumn{2}{|l|}{ Mission: HF 5001-6182 } \\
\hline & \multicolumn{2}{|c|}{ Programme: HF 5546-5548.6, HF 5549-5549.5 } \\
\hline & Paper: & HD 62 \\
\hline \multirow{3}{*}{$\begin{array}{l}\text { Journal of Economic } \\
\text { Literature } \\
\text { (JEL) } \\
\text { Website JEL }\end{array}$} & \multicolumn{2}{|l|}{ Mission: M } \\
\hline & \multicolumn{2}{|c|}{ Programme : M 10, L 2, M 12} \\
\hline & Paper: & L 15 \\
\hline \multicolumn{3}{|c|}{ Gemeenschappelijke Onderwerpsontsluiting (GOO) } \\
\hline \multirow[t]{3}{*}{ Classification GOO } & \multicolumn{2}{|l|}{ Mission: 85.00} \\
\hline & \multicolumn{2}{|c|}{ Programme: $85.05,85.08,85.62$} \\
\hline & Paper: & 85.12 \\
\hline \multirow[t]{3}{*}{ Keywords GOO } & \multicolumn{2}{|c|}{ Mission: Bedrijfskunde / Bedrijfseconomie } \\
\hline & \multicolumn{2}{|c|}{ Programme: Organisatieleer, prestatiebeoordeling, personeelsbeleid } \\
\hline & \multicolumn{2}{|c|}{ Paper: iso-normen, tevredenheid } \\
\hline Free keywords & \multicolumn{2}{|c|}{ ISO 9000, Quality Management, Survey Research } \\
\hline
\end{tabular}




\title{
Perceptions about the ISO 9000 (2000) quality system standard revision and its value: The Dutch experience
}

\author{
Ton van der Wiele ${ }^{1}$ \\ Erasmus University Rotterdam, Room H15-06, PO Box 1738, 3000 DR Rotterdam, \\ The Netherlands, tel. +31104081354 , fax +31104089169 \\ E-mail: vanderwiele@few.eur.nl \\ Jos van Iwaarden \\ Erasmus University Rotterdam, The Netherlands \\ E-mail: vaniwaarden@few.eur.nl \\ Roger Williams \\ Erasmus University Rotterdam, The Netherlands \\ E-mail: williams@few.eur.nl \\ Barrie Dale \\ University of Manchester Institute of Science and Technology, United Kingdom \\ E-mail: barrie.dale@umist.ac.uk
}

\footnotetext{
${ }^{1}$ Corresponding author
} 


\title{
Perceptions about the ISO 9000 (2000) quality system standard revision and its value: The Dutch experience
}

\begin{abstract}
The aim of the research reported in this paper is to assess the relative value of the 2000 version of the ISO 9000 series of quality management system standards in comparison to the 1994 version. 773 organisations in the Netherlands which have all been certified to the ISO 9000 standard were surveyed (a response rate of 21.4\%) and of these only 22 had not yet converted to the 2000 version of the standard. Amongst the major findings are an overall positive perception of the value of the ISO 9000 (2000) quality system standard and a consistently higher appreciation of the 2000 version compared to the 1994 version.
\end{abstract}

Keywords: ISO 9000, Quality Management, Survey Research

\section{Introduction}

The ISO 9000 series of quality system standards (ISO, 2004) and its related certification have been in place for considerable time. Developed from the military standards (e.g. AQAP) and the British Standards (BS 5750) the first international standards, agreed through the International Organisation for Standardisation, were published in 1987 and two upgrades have followed in 1994 and 2000. The initial aim behind the ISO 9000 series was to build confidence between suppliers and manufacturers in business to business transactions and in international trade. They are based on the notion that specific minimum characteristics of quality systems can be standardized, which can yield benefits for organisations as well as for their suppliers because each of them knows that they both meet certain requirements (Tummala and Tang, 1996).

ISO 9000 standards also help to ensure that organisations follow specific welldocumented procedures in the making and/or delivery of their products or services, and nothing more. These procedures are meant to guarantee that the products or services of an organisation are in accordance with customer specifications. Therefore 
it can be said that they are aimed at the assurance of quality consistency rather than at improving the quality of the products or services of an organisation (Tsiotras and Gotzamani, 1996).

ISO 9000 series certification is not a standardized package that can be applied in the same way in every organisation; the standards only detail the essential elements of a formal quality assurance system, without recommending the ways to apply them (Tsiotras and Gotzamani, 1996).

Based on a review of the literature, it is concluded that research on the ISO 9000 series has so far been focused on a number of issues, which can be fitted into the following six part classification:

- $\quad$ The relationship between ISO 9000 and TQM - does ISO 9000 contribute to the TQM journey? (Askey and Dale, 1994; Bradley, 1994; Stephens, 1994; Meegan and Taylor, 1997; Van der Wiele et al., 1997; Brown et al., 1998; Kanji, 1998; Quazi and Padibjo, 1998; McAdam and McKeown, 1999; Lee, 1995; Jones et al., 1997; Singels et al., 2001; Yahya and Goh, 2001; Williams, 1997; Kochan, 1993; Brecka, 1994).

- Perceptions about the benefits of ISO 9000 - do the benefits exceed the costs of implementation? (Singels et al., 2001; Llopis and Tarí, 2003).

- The relationship between ISO 9000 and organisational improvement - does it lead to organisational improvements? (Heras et al, 2002; Buzzel and Wiersema, 1981; Craig and Douglas, 1982; Phillips et al., 1983; Jacobson and Aaker, 1987; Capon et al., 1990; Rust et al., 1994; Maani et al., 1994; Flynn et al., 1995 and 1997; Forker et al., 1996; Caruana and Pitt, 1997; Adam et al., 1997; Ebrahimpour et al., 1997; Mann and Kehoe, 1994; Buttle, 1997; Quazi and Padibjo, 1998; Lloyd's Register of Quality Assurance, 1993; Institute of Quality Assurance, 1993; Brecka, 1994; Terziovski et al., 1997; Corrigan, 1994; Henkoff, 1993; Johannsen, 1995; Stephens, 1994).

- $\quad$ The usefulness of ISO 9000 for different sizes and types of organisations - is it universally applicable to all types of situations? (Brown et al, 1998; Heras et al, 2002).

- $\quad$ The long-term effects of ISO 9000 - does implementation lead to long lasting improvements? (Gotzamani and Tsiotras, 2001; Terziovski et al., 2003). 
- $\quad$ The motivation to implement ISO 9000 - is pressure within the supply chain and/or governmental regulation more important than quality improvement? (Gotzamani and Tsiotras, 2001).

Although most of the literature on the business value of ISO 9000 quality systems has been criticised by writers such as Heras et al (2002) as consisting mainly of articles that are either anecdotal, case study based, or report descriptive statistics from questionnaire surveys, it can be concluded that there is evidence from various business sectors and countries on the positive impact of ISO 9000 series standards. In the main, research suggests that companies only try and acquire an ISO 9000 certificate under pressure. This pressure can come from customers, head office or government rules. A possible cause of reluctance to act on their own initiative may be the scepticism which is also reported about the contribution of the standards and certification to business economic performance improvement. When companies are forced down the ISO 9000 route then the approach will be minimalistic (Brown and Van der Wiele, 1996) in terms of the seriousness with which the system is developed and the degree to which it is linked to more general business goals.

In order to keep up with modern developments, the International Organisation for Standardisation carries out a revision of its standards on a regular basis and a radically revised ISO 9000 standard was published in 2000. All organisations holding a certificate of registration to the 1994 version of the standard were given until the end of 2003 to meet the requirements of the new 2000 standard. If they failed to meet this deadline then their registration would lapse.

Based on a review of the literature it appears that there is a paucity of research which compares the views of businesses on the 1994 and 2000 versions of the standard. The aims of the research described in this paper are to see if and how organisations made the conversion and how they assess the value of the revised ISO 9000 standard. The research examines a number of aspects of this conversion that companies had to go through in order to develop their quality management systems to meet the requirements of the 2000 version of the ISO 9000 series of standards. The research addresses the following three main issues:

- Are companies dissatisfied with the standard because they did not experience any major improvements in the past from their certification? 
- How fundamental do they perceive the changes they have to make in order to conform to the 2000 version of ISO 9000 series standard?

- In what ways, if at all, do companies perceive the 2000 version of the ISO 9000 series standard an improvement in comparison to the 1994 version?

An overview will now follow of the possible problems caused by the changes that are demanded in the 2000 version of the ISO 9000 series standard in comparison to the 1994 version. Thereafter the research methodology is explained and the results presented.

\section{Possible problems caused by the changes in the ISO 9000 series standard}

As an introduction to our research on the views of businesses on the versions of the ISO 9000 standard informal discussions have been undertaken with various practitioners in the UK and the Netherlands. From this a number of views have emerged regarding possible problems and difficulties likely to be involved in implementing the 2000 version of the standard.

It is suggested, that the 1987 and 1994 versions of the ISO 9000 series produced minor cost savings and held few clear benefits for both suppliers and customers, especially after the system has been firstly implemented. The 2000 version could be considered as involving higher development and maintenance costs and having even fewer clear benefits. For example, by adopting these early versions, suppliers had been able to reduce costs because they had to entertain fewer audit teams, using differing audit systems, from their many different customers. Customers also welcomed earlier versions because they saved them the cost involved in auditing their suppliers.

Moreover, it was easy to understand what the certificates actually measured. The standards were a measure of avoidance of failure and if an organisation did not do the things identified in the various requirements of ISO 9001, 9002 or 9003, there was a high chance of failure. If it did do these things, there was no guarantee of success, but at least there was little chance of major failure. In contrast, the benefits of the 2000 version with the new requirements relating to business processes, continuous improvement, product, planning, employee involvement, etc. are far less clear. 
The type of internal auditor required also changes. The work required of internal auditors for the 1994 series was relatively simple and internally orientated and thus they often came from the quality function. In general, these auditors are not equipped to audit the very different kinds of areas covered by the new 2000 standard and thus auditors with a more senior management background are needed. And these are likely to be far less easily available.

Acquiring certification to ISO 9000 (1994) cost the organisation little as no major changes to organisational structure or systems and little senior management involvement were needed. The quality function had the main responsibility. In contrast, the new requirements of the 2000 revisions - business processes, continuous improvement, and involving people - necessitate major change and thus high costs. For example, they require top management to take what tend to be quite sensitive decisions (e.g. appointing process owners) and they require the involvement of all, rather than just the quality, functions.

Changes are also required to some internal management and control systems. ISO 9000 (1994) could be implemented without major changes being needed in too many existing organisational management and control systems. But now senior management have to provide adequate resources to ensure the changes demanded by the 2000 revision actually can become a reality. This will therefore cost money. And yet most senior management are still measured and controlled against systems that do not support this approach (e.g. they have direct versus indirect staff ratios as control targets).

Again senior management are monitored and rewarded on the basis of satisfying shareholders (and themselves often as major shareholders)! And this is often quite a short-term strategy. But ISO 9000 (2000) is aimed at satisfying the customer; and often this only shows its value over the longer term and in a relatively stable environment. In our view we would expect only a small number of companies are likely to be in the situation where they can wait for the long term value of increasing customer satisfaction to show itself.

A final problem, caused by the major changes involved in the ISO 9000 quality system standard, concerns the auditing of the standards. For example, it has been suggested that the 2000 version is still too generic and that many auditors and 
organisations are interpreting it in a liberal manner. It has also been remarked that only a small number of certification bodies are getting organisations in the spirit of the standard, to think in terms of business and processes. A large number of auditors are regarded as having difficulties in moving from the previous compliant regime and are still using 'lists of questions' to probe issues relating to the requirements. It is suggested that these auditors appear to have a lack of knowledge about how to implement and audit against the requirements of the new standard. They are also struggling with the focus on continuous improvement instead of the previous aim of merely maintaining the achieved level of quality assurance. This type of problem is attenuated when the certification body is also acting as the advising consultant to the organisation.

Finally there is some suggestion amongst the practitioners that difficulties are being experienced in interpreting many of the clauses and that some organisations will be awarded a certificate of registration, even if their situation is less than perfect. The rationale given is that such organisations will be brought into line when assessors will have gained more experience.

In summary, it is clear that the 2000 revision of the ISO 9000 quality system standard brings major changes for all three parties involved, customers, suppliers and auditors. It is therefore interesting to see how those who have opted to be re-certified under the new 2000 series view the new world they now face.

\section{Research methodology}

Based on the literature and informal discussions with practitioners a number of issues have been identified in relation to ISO 9000 (2000). These can be broadly grouped into two categories:

- Managing the changes required

how have the changes been managed in relation to the 2003 deadline?

what advice is available and how useful is it?

how is it improving the management of the organisation with respect to quality?

is it leading organisations to question the benefits of registration? 
- Perceived differences in the 2000 and 1994 versions of the standard

> which elements of the 2000 version will improve the way a business is managed and its performance?

$>$ is it more user friendly and attractive to potential users?

$>$ what changes, if any, have management made to their behaviour?

$>$ what are the benefits and what criticisms remain?

$>$ is there any competitive advantage?

These issues have lead to the formulation of the following research propositions:

- The increased demands of the new 2000 version will make the conversion more costly and therefore some organisations may decide not to convert and lose their certificate.

- Disappointment with the costs against benefits balance in relation to the 1994 version will be a reason for some organisations not to convert.

- The 2000 version will stimulate some organisations to move up the quality maturity ladder and by doing so will contribute to organisational efficiencies and profitability.

The empirical research has taken place by means of a survey. Questionnaire based research is an appropriate approach in relation to the issues identified, and is especially applicable in relation to the measurement of perceptions on the issues involved (Yin, 2003). The questionnaire used consists of the following blocks of questions:

- Personal and organisational information

- Issues related to the conversion to meet the requirements of the 2000 version

- Perceptions of the success of the 1994 and 2000 versions of the standard

- A number of statements about the previous and the new ISO 9000 quality system standards

The sample was chosen with the co-operation of four of the major certification bodies in the Netherlands: KEMA, TUV, DNV and KIWA. These four cover approximately 
$30 \%$ of all certified organisations in the Netherlands. Each of them was requested to make available the contact details of all organisations for which they had awarded certification and each provided around 1000 organisations. All these organisations received a hard copy of the questionnaire together with a cover letter and prepaid return envelope. This material carried both the logo of Erasmus University and that of the certification body. The sample sizes and response rates are given in table 1 . The response rate of over $20 \%$ was regarded as being very satisfactory in comparison to other postal surveys.

\section{$\underline{\text { Take in Table } 1}$}

Initiatives are currently taken to expand the research to other countries: Ireland, UK, Germany, France, Switzerland, Spain, Hong Kong, USA and Australia. This paper covers the results of the analyses of the Dutch data. This is a truly unique research project, because approximately one out of every three certified organisations in the Netherlands received the questionnaire. This, together with the relatively high response rate, means that these results could be regarded as representative of all Dutch ISO 9000 certified organisations.

\section{Descriptive results}

\section{Respondents and respondents' organisations}

The background of the respondents and their companies is summarised in table 2. It can be seen that in most cases the respondent is the quality manager. However, in companies with less than 50 employees the respondent is more often the general manager. The response group is well balanced in terms of manufacturing/service organisations. However, non-profit/governmental organisations form only $10 \%$ of the response group. There is also an equal split between small (less than 50 employees) and medium sized organisations (51-250 employees). There seems to be no major differences between the certification bodies in terms of the background of the respondents and the characteristics of their organisations. 


\section{Take in Table 2}

Figure 1 indicates the date of first certification for the various sub samples. Some organisations report being certified before ISO 9000 was first started in 1987; they are probably referring to their being certified to one of the military standards which were already in place before the ISO 9000 series of standards was introduced. The four different certification bodies do not portray the same picture. It might be assumed that respondents of KEMA have had experiences with ISO 9000 quality management systems and its certification for a longer period.

\section{$\underline{\text { Take in Figure } 1}$}

The large majority of the sample reported that their organisation had already implemented and been certified against the 2000 version of ISO 9000. Only 22 out of a total sample of 790 respondents indicated that they had not yet converted. Of these, 9 said they were planning to convert; another 4 had not yet decided and only 9 respondents indicated that they had no plans to convert. This provides strong evidence that most ISO 9000 series certified organisation did, as required, make the conversion before the defined deadline (December 2003). Reasons for not having converted yet include: requires too much management time (8 responses), too costly (5 responses), customers have stopped requesting it (5 responses), and lack of perceived benefits (3 responses). The reasons for not planning to convert are outside the scope of ISO 9000 series standards (e.g. change of ownership, business termination).

Some seventy respondents (9.1\%) indicated that they had changed their certification body in making the conversion. The reasons for the change are: unsatisfactory surveillance visits (21 responses), certification fees were too high (16 responses), auditors were not approachable (12 responses) and lack of auditor expertise (8 responses). It seems that the majority of these reasons are related to the organisation and arrangement of the surveillance audits and the communication between the organisation and the auditor and the certification body. 


\section{Conversion}

The reasons cited for conversion to the 2000 version of the ISO 9000 series standard are interesting. Table 3 shows that often the motivation has come from internal sources. On a five point scale, quality managers and general managers score 4.19 and 3.63 respectively, so it is clear that these two parties have played a major role in their organisation's decision to convert. It is surprising perhaps that customers, certification bodies, branch/trade organisations and other companies had a low influence on the conversion.

\section{$\underline{\text { Take in Table } 3}$}

Table 4 summarises respondents' views on the extent to which specific issues formed a problem during the conversion. The relatively low scores on all the issues indicate that the conversion was not seen as problematic for most companies. The top four are the same problems which have appeared in previous research (e.g. Binney, 1992; Lloyd's Register of Quality Assurance, 1993; Taylor, 1995; Brown and Van der Wiele, 1996; Seddon, 1997) on the implementation of both the 1987 and 1994 versions of the ISO 9000 standard: time required, implementation of the requirements, interpretation of the requirements, and the costs involved.

\section{$\underline{\text { Take in Table } 4}$}

Table 5 summarises responses concerning the extent to which a number of different changes were required in order to make the conversion. The most important change respondents consider to be necessary are in management behaviour. This is hardly surprising as the broader quality management scope of the 2000 version places increased demands on management. For example, it requires from management a clearer view on the quality strategy and requires actual management behaviour to be supportive of that quality strategy. Other important aspects cited as needing changes in relation to the conversion are: the quality manual, the improvement approach, the customer orientation and management control. 


\section{Take in Table 5}

\section{Appreciation of the 2000 version of ISO 9000}

As table 6 shows, respondents perceive the 2000 version of ISO 9000 as better than the 1994 version on virtually all aspects presented. They are especially satisfied with the two most significant changes that have been incorporated into the 2000 version of the standard: the stronger focus on customer orientation and on the improvement approach. The only aspect on which respondents regard the 1994 version as being better is, perhaps unsurprisingly, the costs related to the certification process.

Respondents consider both versions to be equally good/bad when it comes to the amount of time needed to complete the certification process.

\section{Take in Table 6}

Respondents were asked to assess the value of ISO 9000 (2000) certification in comparison to ISO 9000 (1994). A mean value of 3.70 leads to the conclusion that, in their view, the former is a major improvement. Table 7 shows respondents' answers to questions probing in more depth why the 2000 version of the standard might be more/less valuable than the previous version. On all statements respondents rate the 2000 standard higher than the 1994 version. For example, the way the ISO 9000 quality system operates in the organisation of the respondents scored much higher for the 2000 version (3.49 for the 2000 version against 3.00 for the 1994 version on a five point scale). Again the 2000 version was seen to have achieved expected benefits to a greater degree than 1994 version (3.32 to 2.96). And the 1994 system was seen to have consumed too much time and resources compared to the 2000 version. (2.88 for the 2000 version and 3.13 for the 1994 version on the negatively formulated statement).

\section{Take in Table 7}


The questionnaire sought to investigate to what degree the two ISO 9000 versions (1994 and 2000) effected important aspects of the organisation and its business. A list of 19 aspects were identified that reflect important business enablers (e.g. management control, leadership, customer focus, teamwork, efficiency in processes, scrap, rework, continuous improvement) and important business outcomes (e.g. customer satisfaction, employee satisfaction, quality of products, quality of service, brand/image, customer loyalty/repeat business) and for each of these 19 aspects, respondents were asked to indicate (on a five point scale from 1= major negative effect to $5=$ major positive effect) the extent to which they perceive negative or positive effects to flow from of the 1994 version and the 2000 version. Table 8 shows the scores on the 19 aspects and the differences between the 2000 and the 1994 version.

\section{$\underline{\text { Take in Table } 8}$}

In general respondents perceived both versions of the ISO 9000 series of standards to have positive rather than negative effects on the business. However, there was a difference between the aspects scoring highest for the two versions. Those that score highest for the 2000 version are (ranked according to score): continuous improvement, management control, quality focus, efficiency of processes and customer focus. In contrast, aspects scoring highest for the 1994 version are: quality focus, brand/image, quality of service, market share and efficiency of processes. These findings suggest that perceptions in relation to the 1994 version have been strongly linked to external performances and goals (and thus linked to results aspects), while in contrast, in relation to the 2000 version, the perceptions are linked to internal aspects (and thus linked to enablers aspects).

The lowest scores, i.e. where the ISO 9000 system has either a negative effect or very little effect at all, were similar for both the 1994 and 2000 versions. These were in the areas of employee satisfaction, employee turnover, employee absence, and scrap in processes and rework. From this it would be tempting to conclude that ISO 9000 has little positive impact on employee attitudes and behaviour but in this respect there is an interesting difference that should be noted. In relation to the point made earlier 
about the need for more management involvement in the 2000 version, it is interesting to note that the leadership aspect scored in the bottom five in relation to the 1994 version, while in relation to the 2000 version leadership appeared on the sixth place in terms of the delta between the 2000 and the 1994 scores. Here again perhaps can be seen that the 2000 version is demanding much more active involvement and leadership from management.

Another question in the survey concerned the meaning which respondents gave to the two quality systems. Table 9 shows the results. The largest difference between the 1994 and 2000 versions is that the 2000 version is seen as much more of a management control tool than its predecessor (3.05 versus 3.89). It is also seen as more a driver of innovation (2.52 versus 3.07 ) and perhaps therefore not surprisingly as playing a much more strategic role in the organisation (2.83 and 3.24). As might be expected, the two versions are seen as similar in that they are both quality systems, the role they both play in the organisation has the same importance and neither is regarded as being very backward looking.

\section{$\underline{\text { Take in Table } 9}$}

\section{Statistical analyses}

The descriptive data shows that, overall, respondents have a positive perception about the 2000 version of the ISO 9000 standard and are, in general, satisfied with the changes that it demands. Further analyses have been undertaken to examine how a range of factors (e.g. job title, manufacturing/service sector of respondents' organisations, size of respondents' organisations, and year of first certification) influence (a) the appreciation of the 2000 version in comparison to the 1994 version, (b) the assessment of the value of the 2000 version in comparison to the 1994 version and (c) the effects of the two versions on organisational and management aspects.

Job title of the respondent: difference between general managers and quality managers. 
It might be expected that quality managers have a more positive view on initiatives related to quality management, because they are more involved and are responsible for the conversion from the old to the new standard. General managers are expected to be more sceptical because they have broader responsibilities and more business priorities to consider.

Indeed, quality managers indicate significantly $(\mathrm{p}<0.05)$ higher appreciation on nearly all aspects for the 2000 version. Moreover, general managers and quality managers are significantly different $(p=0.06)$ in their assessment of the value of an ISO 9000 (2000) certification in comparison to ISO 9000 (1994) certification. The ttests undertaken on appreciation and value are summarised in table 10.

\section{$\underline{\text { Take in Table } 10}$}

To examine the specific views of general managers and quality managers on the expected effects of the 1994 and 2000 versions of the ISO 9000 quality system standard, factor analysis was undertaken on the difference between the scores given for the 2000 and the 1994 versions. The analysis on the delta-scores with respect to the expected effects of the ISO 9000 quality system standard (summarised in table 11) gave a reliable four factor solution, with the following factors:

1. A 'quality philosophy' factor, with the following aspects: Management control, Leadership, Customer focus, Customer satisfaction, Continuous improvement and Employee satisfaction.

2. An 'operational effects of the quality system' factor, with the following aspects: Employee absence, Scrap in processes, Rework, Employee turnover, Teamwork and Efficiency of processes.

3. A 'marketing aspects' factor, with the following aspects: Market share, Attraction of new customers, Customer loyalty/Repeat business and Brand/Image.

4. A 'product/service quality' factor, with the following aspects: Quality of products, Quality of service and Quality focus. 


\section{Take in Table 11}

A t-test on those four factors to check for different expectations of general managers and quality managers indicated that there are significant differences in relation to the 'quality philosophy' and the 'product/service quality' factors (see table 12). On these two factors the perceptions about the effects of the ISO 9000 quality systems are significantly different between general managers and quality managers. Quality managers have a more positive perception of the improvement of the 2000 version compared to the 1994 version in relation to the expected effects. On the factors regarding operational aspects and regarding marketing aspects no significant differences between the perceptions of general managers and quality managers were found.

\section{$\underline{\text { Take in Table } 12}$}

In summary:

- quality managers have a higher level of appreciation for the 2000 version;

- quality managers and general managers do not significantly differ in their assessment of the value of certification against the 2000 version; and

- quality managers and general managers do differ in their perceptions on the effects of some organisational and management aspects.

\section{Manufacturing/service sector of respondents' organisations}

As mentioned earlier, there was a nearly equal split in the sample between manufacturing organisations and service organisations. The results of the t-tests did not show any significant differences between perceptions of respondents from manufacturing and service organisations on 'the appreciation of the 2000 version against the 1994 version', 'the assessment of the value of the 2000 version compared to the value of the 1994 version', and neither on 'respondents perceptions of the effects' of the two versions on organisational and management aspects. 
This indicates that, although service organisations might be considered as lagging behind manufacturing organisations in their experiences with quality management, they seem to have no major problems with the interpretation of the ISO 9000 quality system standard to specific service environments and settings.

\section{Size of respondents' organisations}

Correlation tests have been undertaken between size of respondents' organisations and 'appreciation of the 2000 version against the 1994 version', 'assessment of the value of the 2000 version compared to the 1994 version', and 'effects of the two versions'. Larger organisations show significant higher scores on respondents’ appreciation of the 2000 version compared to the 1994 version only for a few aspects (i.e. customer orientation, management behaviour, process control, improvement approach, and management control). There is a significant (positive) correlation between size of the organisation and the perceived value of the 2000 version compared to the value of the 1994 version. The correlation between size and the four factors on the perceived effects (for the factors, see table 11) indicates that respondents of larger organisations do perceive larger effects on aspects related to 'quality philosophy' and 'operational effects'.

\section{Year of first certification}

Based on the analyses in relation to the year in which respondents' organisation first received an ISO 9000 certificate of registration, no significant differences could be found with respect to either appreciation of ISO 9000, nor to assessment of its value, nor to perceived effects of ISO 9000. This is a somewhat unexpected finding, because the assumption was that the more recent the organisation got certificated for the first time, the less experienced it is with ISO 9000 quality management systems and thus false expectations might exist.

\section{Conclusions}

The results of this study suggest that, at least as far as this sample is concerned, the ISO 9000 (2000) revision has achieved many of its goals. Respondents have a more 
realistic understanding of what ISO 9000 quality systems mean for their organisation, and also a more realistic understanding of their value. There is a change in management thinking from ISO 9000 solely related to quality, towards ISO 9000 becoming a management control instrument in relation to the overall business strategy. On all questions and statements used in the questionnaire, the ISO 9000 (2000) version quality system is seen as an improvement in relation to the 1994 version. And the move to adopt ISO 9000 (2000) is not dictated, as older versions often were by external forces of customers, head offices and governments, but was rather a carefully considered internally made decision.

None of the possible problems and difficulties of implementing the 2000 version appeared to concern respondents. The picture painted is a highly positive one. Few regard the required conversion as too difficult or costly and the fact that it is too early yet to relate adoption of the 2000 version to improved organisational performance does not dampen respondents' enthusiasm. And it seems indeed as if some organisations have been stimulated by the 2000 version to move up the quality maturity ladder.

These views cannot be dismissed easily since they are the opinions of experienced managers. All respondents in the sample had previous experience with implementing quality systems. Their perceptions were thus of value because they had relevant comparative material upon which to base their judgements

But this prior experience could of course also be seen as a possible weakness of the study. Although the sample was large and over $20 \%$ of those surveyed, the respondents could be all "believers" in ISO systems. They could all be biased in favour of these systems because they had been themselves involved in the decisions to implement them and they were aware that this implementation was expensive in terms of organisational resources and management time. It could therefore be argued that those who were largely responsible for the implementation of such a costly innovation are hardly likely to be too strong and too open in their criticisms.

Nearly eighty per cent of those approached, all of whom had experience of working with ISO 9000 (1994) refused or were unable to co-operate in the study. It could be that their views might have been much more negative and therefore they did not respond. However the questionnaire gave ample scope for those who wished to point 
out problems and difficulties and to be more negative about the 2000 version of ISO 9000. So as with many such surveys it is more likely that non-respondents either had less time available to fill in the questionnaire or regarded ISO 9000 as of less importance - or both.

But one conclusion can be made with certainty. There are a great many managers in the Netherlands who report feeling very positive about the latest version of the ISO 9000 series of quality management systems.

\section{References}

Adam, E.E. Jr, Corbett, L.M., Flores, B.E., Harrison, N.J., Lee, T.S., Rho, B., Ribera, J., Samson, D. and Westbrook, R. (1997), “An international study of quality improvement approach and firm performance”, International Journal of Operations and Production Management, Vol 17 No 9, pp. 842-73.

Askey, J.M. and Dale, B.G. (1994), “From ISO 9000 series registration to total quality management, an examination”, Quality Management Journal, July, pp. 67-76.

Binney, G. (1992), Making Quality Work: Lessons From Europe’s Leading Companies, The Economist Intelligence Unit, London, Special Report No. P655.

Bradley, M. (1994), “Starting total quality management from ISO 9000”, The TQM Magazine, Vol 6 No 1, pp. 50-4.

Brecka, J. (1994), “Survey of registrars for ISO 9000: prices down, success rate up”, Quality Progress, February, pp. 20-1.

Brown, A. and Wiele, A. van der (1996), “A Typology Of Approaches To ISO Certification And TQM”, Australian Journal of Management, Vol 21 No 1, pp. $57-72$.

Brown, A., Loughton, K. and Wiele, A. van der (1998), “Smaller enterprises’ experiences with ISO 9000”, International Journal of Quality and Reliability Management, Vol 15 No 3, pp. 273-85.

Buttle, F. (1997), “ISO 9000: marketing motivations and benefits”, International Journal of Quality and Reliability Management, Vol 14 No 9, pp. 939-47. 
Buzzel, R.D. and Wiersema, F.D. (1981), "Modelling changes in market share: a cross sectional analysis”, Strategic Management Journal, Vol 2 No 1, pp. 27-42.

Capon, N., Farley, J.U. and Hoening, S. (1990), “Determinates of financial performance: a meta analysis”, Management Science, Vol 36 No 10, pp. 114359.

Caruana, A. and Pitt, L. (1997), “INTQUAL - an internal measure for service quality and the link between service quality and business performance”, European Journal of Marketing, Vol 31 No 8, pp. 604-17.

Corrigan, J. (1994), “Is ISO 9000 the path to TQM?”, Quality Progress, May, pp. 336.

Craig, C.S. and Douglas, S.P. (1982), "Strategic factors associated with market share and financial performance”, Quarterly Review of Economics and Business, Summer, pp. 101-11.

Ebrahimpour, M., Withers, B.E. and Hikmet, N. (1997), “Experiences of US- and foreign-owned firms: a new perspective on ISO 9000 implementation”, International Journal of Production Research, Vol 35 No 2, pp. 569-76.

Flynn, B.B., Schroeder, R.G. and Sakakibara, S. (1995), “The impact of quality management practices on performance and competitive advantage”, Decision Sciences, Vol 26 No 5, pp. 659-92.

Flynn, B.B., Schroeder, R.G., Flynn, E.J., Sakakibara, S. and Bates, K.A. (1997), "World-class manufacturing project: overview and selected results", International Journal of Operations \& Production Management, Vol 17 No 7, pp. 671-85.

Forker, L.B., Vickery, S.K. and Droge, C.L. (1996), “The contribution of quality to business performance”, International Journal of Operations and Production Management, Vol 16 No 8, pp. 44-62.

Gotzamani, K.D. and Tsiotras, G.D. (2001), “An empirical study of the ISO 9000 standards' contribution towards total quality management”, International Journal of Operations \& Production Management, Vol 21 No 10, pp.1326-42.

Henkoff, R. (1993), “The hot new seal of quality”, Fortune, 28 June, pp. 68-71. 
Heras, I., Casadesus, M. and Dick, G.P.M. (2002), “ISO 9000 certification and the bottom line: a comparative study of the profitability of Basque companies”, Managerial Auditing Journal, Vol 17 No 1/2, pp.72-8.

Institute of Quality Assurance (1993), Survey on the Use and Implementation of BS5750, Institute of Quality Assurance, London.

International Organisation for Standardization (ISO) (2004), The ISO Survey of ISO 9000 and ISO 14000 Certificates (Twelfth Cycle), International Organisation for Standardisation, Geneva.

Jacobson, R. and Aaker, D. (1987), “The strategic role of product quality”, Journal of Marketing, Vol 51 No 4, pp. 31-44.

Johannsen, C.G. (1995), “Application of the ISO 9000 standards of quality management in professional services: an information sector case”, Total Quality Management, Vol 6 No 3, pp. 231-42.

Jones, R., Arndt, G. and Kustin, R. (1997), “ISO 9000 among Australian companies: impact of time and reasons for seeking certification on perceptions of benefits received”, International Journal of Quality and Reliability Management, Vol 14 No 7, pp. 650-60.

Kanji, G.K. (1998), “An innovative approach to make ISO 9000 standards more effective”, Total Quality Management, Vol 9 No 1, pp. 67-78.

Kochan, A. (1993), “ISO 9000: creating a global standardisation process”, Quality, October, pp. 26-34.

Lee, T. (1995), “The experience of implementing ISO 9000 in Hong Kong”, Asia Pacific Journal of Quality Management, Vol 4 No 4, pp. 6-16.

Llopis, J. and Tarí, J.J. (2003), “The importance of internal aspects in quality improvement”, International Journal of Quality and Reliability Management, Vol 20 No 3, pp. 304-24

Lloyd's Register of Quality Assurance (1993), Setting standards for better business, Report of Survey Findings, Lloyds, London. 
Maani, K.E., Putterill, M.S. and Sluti, D.G. (1994), “Empirical analysis of quality improvement in manufacturing”, International Journal of Quality and Reliability Management, Vol 11 No 7, pp. 19-37.

Mann, R. and Kehoe, D. (1994), “An evaluation of the effects of quality improvement activity on business performance”, International Journal of Quality and Reliability Management, Vol 11 No 4, pp. 29-44.

McAdam, R. and McKeown, M. (1999), "Life after ISO 9000: an analysis of the impact of ISO 9000 and total quality management on small businesses in Northern Ireland”, Total Quality Management, Vol 10 No 2, pp. 229-41.

Meegan, S.T. and Taylor, W.A. (1997), "Factors influencing a successful transition from ISO 9000 to TQM: the influence of understanding and motivation”, International Journal of Quality \& Reliability Management, Vol 14 No 2, pp. 100-17.

Phillips, L.W., Chang, D.R. and Buzzel, R.D. (1983), "Product quality, cost position, and business performance: a test of key hypotheses”, Journal of Marketing, Vol 37 No 1, pp. 26-43.

Quazi, H.A. and Padibjo, S.R. (1998), “A journey towards total quality management through ISO 9000 certification. A study of small and medium sized enterprises in Singapore”, International Journal of Quality \& Reliability Management, Vol 15 No 5, pp. 364-71.

Rust, R.T., Zahorik, A.J. and Keiningham, T.I. (1994), “Return on quality (ROQ): making service quality financially accountable”, Journal of Marketing, Vol 59 No 2, pp. 58-70.

Seddon, J. (1997), “Ten arguments against ISO 9000”, Managing Service Quality, Vol 7 No 4, pp. 162-8.

Singles, J., Ruel, G. and Van de Water, H. (2001), "ISO 9000 series - certification and performance”, International Journal of Quality and Reliability Management, Vol 18 No 1, pp. 62-75.

Stephens,K.S. (1994), “ISO 9000 and total quality”, Quality Management Journal, Vol 2 No 1, pp. 57-71. 
Taylor, W.A. (1995), “Senior executives and ISO 9000”, The International Journal of Quality and Reliability Management, Vol 12 No 4, pp. 40-57.

Terziovski, M., Samson, D. and Dow, D. (1997), “The business value of quality management systems certification: evidence from Australia and New Zealand”, Journal of Operations Management, Vol 15 No 1, pp. 1-18.

Terziovski, M., Power, D. and Sohal, A.S. (2003), “The longitudinal effects of the ISO 9000 certification process on business performance”, European Journal of Operational Research, No 146 (3), pp. 580-95.

Tsiotras, G. and Gotzamani, K. (1996), "ISO 9000 as an entry key to TQM: the case of the Greek industry”, International Journal of Quality and Reliability Management, Vol 13 No 4, pp. 64-76.

Tummala, V.M.R. and Tang, C.L. (1996), “Strategic quality management, Malcolm Baldrige and European Quality Awards and ISO 9000 certification: core concepts and comparative analysis”, International Journal of Quality and Reliability Management, Vol 13 No 4, pp. 8-38.

Wiele, A. van der, Dale, B.G. and Williams, A.R.T. (1997), “ISO 9000 series registration to total quality management: the transformation journey”, International Journal of Quality Science, Vol 2 No 4, pp. 236-52.

Williams, N. (1997), "ISO 9000 as a route to TQM in small to medium sized enterprises: snake or ladder?”, The TQM Magazine, Vol 9 No 1, pp. 8-13.

Yahya, S. and Goh, W.-K. (2001), “The implementation of an ISO 9000 quality system”, International Journal of Quality and Reliability Management, Vol 18 No 9, pp. 941-66.

Yin, R.K. (2003), Case Study Research: Design and Methods (3rd edition), Sage Publications, London. 
$\underline{\text { Table 1: Sample sizes and response rates }}$

\begin{tabular}{|lccc|}
\hline \multicolumn{1}{r}{ Certification Institute } & $\begin{array}{c}\text { Sample size } \\
(\mathrm{N})\end{array}$ & $\begin{array}{c}\text { Response } \\
(\mathrm{N})\end{array}$ & $\begin{array}{c}\text { Rate } \\
(\%)\end{array}$ \\
KEMA & 788 & 200 & $25.4 \%$ \\
TUV & 1089 & 201 & $18.5 \%$ \\
DNV & 882 & 221 & $25.1 \%$ \\
KIWA & 847 & 151 & $17.8 \%$ \\
Total sample & 3606 & 773 & $21.4 \%$ \\
\hline
\end{tabular}


$\underline{\text { Table 2: Background of respondents and organisations }}$

\begin{tabular}{|rccccc|}
\hline \multicolumn{1}{|c}{$\begin{array}{c}\text { Certification body: } \\
\text { Job title respondent }\end{array}$} & Total & KEMA & TUV & DNV & KIWA \\
General manager & 175 & 34 & 51 & 54 & 36 \\
Quality (assurance) manager & 488 & 139 & 116 & 134 & 99 \\
Functional background respondent & & & & & \\
Production & 169 & 38 & 41 & 53 & 37 \\
Marketing & 74 & 18 & 20 & 21 & 15 \\
Research and development & 93 & 25 & 26 & 30 & 12 \\
Sales & 92 & 18 & 29 & 28 & 17 \\
Quality & 313 & 100 & 72 & 95 & 46 \\
Finance \& accounting & 90 & 14 & 31 & 31 & 14 \\
Purchasing & 41 & 11 & 12 & 11 & 7 \\
Logistics & 84 & 15 & 31 & 27 & 11 \\
Business sector & & & & & \\
Manufacturing & 354 & 92 & 91 & 102 & 69 \\
Service & 419 & 88 & 106 & 92 & 70 \\
Less than 10 employees & 84 & 14 & 34 & 21 & 15 \\
$10-50$ employees & 299 & 53 & 105 & 80 & 61 \\
$51-100$ employees & 122 & 38 & 31 & 29 & 24 \\
$101-250$ employees & 130 & 33 & 23 & 48 & 26 \\
more than 250 employees & 136 & 61 & 8 & 42 & 25 \\
\hline
\end{tabular}


Figure 1: Year of first awarding of certificate

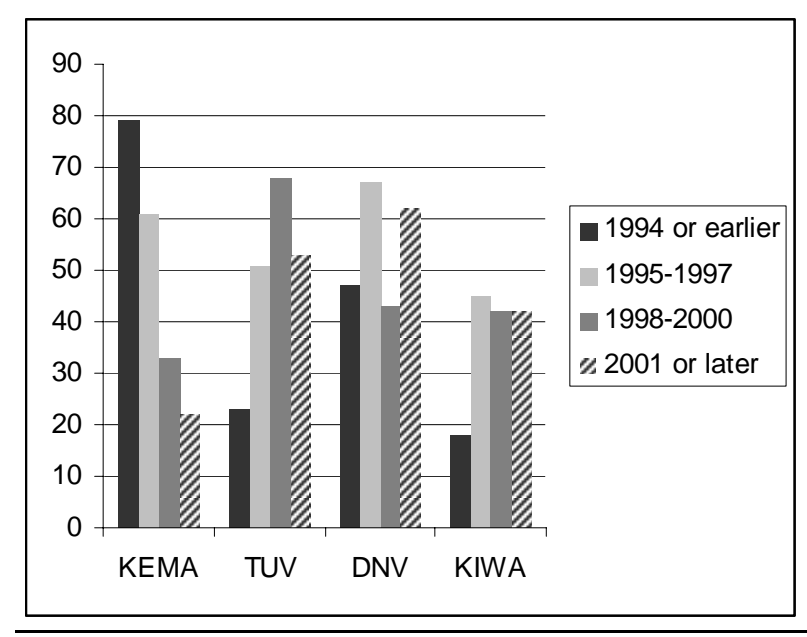


Table 3: Parties influencing the conversion

\begin{tabular}{|lcc|}
\hline & Mean & S.D. \\
Quality (assurance) manager & 4.19 & 1.08 \\
Senior management & 3.63 & 1.27 \\
External auditor & 3.01 & 1.33 \\
Internal auditor & 3.00 & 1.36 \\
Middle management & 2.93 & 1.19 \\
Certification body & 2.76 & 1.31 \\
Customers & 2.22 & 1.31 \\
Consultant & 2.09 & 1.40 \\
Branch/trade organisation & 1.68 & 1.08 \\
Another company & 1.33 & 0.74 \\
Academic institution & 1.18 & 0.52 \\
\hline
\end{tabular}

Scores on a five point scale from $1=$ no influence to $5=$ major influence. 
Table 4: Problems during the conversion

\begin{tabular}{|lcc|}
\hline & Mean & S.D. \\
Time required & 2.74 & 1.19 \\
Implementation of new requirements & 2.63 & 1.11 \\
Interpretation of the new requirements & 2.46 & 1.12 \\
Costs involved & 2.20 & 1.05 \\
Expertise of the auditor & 1.99 & 0.99 \\
Resistance of middle management & 1.92 & 1.01 \\
Resistance of senior management & 1.86 & 1.03 \\
Specific problems within sales & 1.82 & 1.02 \\
Specific problems within production/operations & 1.76 & 0.94 \\
Specific problems within marketing & 1.72 & 0.97 \\
Specific problems within research and development & 1.65 & 0.92 \\
Specific problems within purchasing & 1.65 & 0.86 \\
Specific problems within logistics & 1.55 & 0.80 \\
Specific problems within finance and accounting & 1.52 & 0.79 \\
\hline
\end{tabular}

Scores on a five point scale from $1=$ no problem to $5=$ =major problem 
Table 5: Changes that were required to make the conversion

\begin{tabular}{|lcc|}
\hline & Mean & S.D. \\
Management behaviour & 3.06 & 1.19 \\
Quality manual & 3.01 & 1.24 \\
Improvement approach & 2.87 & 1.13 \\
Customer orientation & 2.84 & 1.24 \\
Management control & 2.83 & 1.14 \\
Process control & 2.72 & 1.19 \\
Quality responsibility & 2.57 & 1.19 \\
Employee involvement & 2.54 & 1.08 \\
Internal Communication & 2.52 & 1.07 \\
Training & 2.21 & 1.03 \\
Service delivery & 2.10 & 1.04 \\
Relationship with suppliers & 2.07 & 1.02 \\
\hline
\end{tabular}

Scores on a five point scale from $1=$ no change to $5=$ major change 
Table 6: The extent to which the 2000 version is better than the 1994 version

\begin{tabular}{|lll|}
\hline & Mean & S.D. \\
Customer orientation & 3.92 & 0.82 \\
Management behaviour & 3.73 & 0.79 \\
Improvement approach & 3.68 & 0.80 \\
Management control & 3.61 & 0.76 \\
Process control & 3.48 & 0.85 \\
Quality manual & 3.35 & 0.81 \\
Quality responsibility & 3.33 & 0.72 \\
Employee involvement & 3.20 & 0.72 \\
Internal Communication & 3.20 & 0.68 \\
Importance of the certification to customers & 3.19 & 0.76 \\
Service delivery & 3.14 & 0.64 \\
Training & 3.10 & 0.65 \\
Relationship with suppliers & 3.06 & 0.67 \\
Time taken to complete the certification process & 3.01 & 0.73 \\
Cost of the certification process & 2.89 & 0.68 \\
\hline
\end{tabular}

Scores on a five point scale from $1=$ the 2000 version is much worse to $5=$ the 2000 version is much better 
Table 7: 2000 version better on various definitions of value

\begin{tabular}{|c|c|c|c|}
\hline & $\begin{array}{c}1994 \\
\text { version }\end{array}$ & $\begin{array}{c}2000 \\
\text { version }\end{array}$ & delta \\
\hline $\begin{array}{l}\text { you are satisfied with the way the ISO } 9000 \text { quality } \\
\text { system operates in your company }\end{array}$ & 3.00 & 3.49 & 0.49 \\
\hline $\begin{array}{l}\text { your organisation's expectations about the benefits of } \\
\text { the ISO } 9000 \text { quality system have been met }\end{array}$ & 2.96 & 3.32 & 0.36 \\
\hline $\begin{array}{l}\text { the ISO } 9000 \text { quality system consumes too much } \\
\text { time and resources }\end{array}$ & 3.13 & 2.88 & $-0.25 *$ \\
\hline $\begin{array}{l}\text { the value of the ISO } 9000 \text { quality system exceeds the } \\
\text { cost of its implementation }\end{array}$ & 2.94 & 3.08 & 0.14 \\
\hline $\begin{array}{l}\text { the value of the ISO } 9000 \text { quality system exceeds the } \\
\text { cost of its maintenance }\end{array}$ & 2.93 & 3.07 & 0.14 \\
\hline
\end{tabular}

Scores on a five point scale from $1=$ strongly disagree to 5 =strongly agree; * = negatively formulated statement 
Table 8: Negative and positive effects of the ISO 9000 quality system

\begin{tabular}{|lccc|}
\hline & 1994 & 2000 & delta \\
Customer focus & 3.10 & 3.68 & 0.59 \\
Efficiency of processes & 3.19 & 3.78 & 0.58 \\
Customer satisfaction & 3.15 & 3.68 & 0.53 \\
Quality focus & 3.35 & 3.82 & 0.47 \\
Quality of service & 3.23 & 3.68 & 0.45 \\
Leadership & 3.00 & 3.43 & 0.43 \\
Teamwork & 3.06 & 3.38 & 0.33 \\
Employee satisfaction & 2.87 & 3.16 & 0.29 \\
Quality of products & 3.19 & 3.46 & 0.27 \\
Customer loyalty/Repeat business & 3.16 & 3.42 & 0.26 \\
Scrap in processes & 3.02 & 3.26 & 0.24 \\
Brand/Image & 3.25 & 3.46 & 0.21 \\
Rework & 3.05 & 3.22 & 0.18 \\
Attraction of new customers & 3.15 & 3.33 & 0.17 \\
Market share & 3.20 & 3.35 & 0.14 \\
Employee turnover & 2.91 & 3.05 & 0.14 \\
Employee absence & 2.93 & 2.99 & 0.07 \\
Continuous improvement & 3.15 & 3.85 & 0.70 \\
Management control & 3.16 & 3.82 & 0.66 \\
\hline
\end{tabular}

Scores on a five point scale from 1 =major negative effect to 5 =major positive effect 
Table 9: The meaning of ISO 9000 quality systems

\begin{tabular}{|lccc|}
\hline & 1994 & 2000 & delta \\
ISO 9000 is a management control tool & 3.05 & 3.89 & 0.84 \\
ISO 9000 is a driver of innovation & 2.52 & 3.07 & 0.54 \\
ISO 9000 plays a strategic role in my organisation & 2.83 & 3.24 & 0.41 \\
An ISO 9000 certificate of registration is a sign of quality & 3.03 & 3.36 & 0.33 \\
ISO 9000 is a quality system & 3.39 & 3.66 & 0.27 \\
ISO 9000 is a backward-looking instrument which monitors & 2.87 & 2.64 & $-0.23^{*}$ \\
the past & 2.81 & 2.72 & $-0.09^{*}$ \\
ISO 9000 plays a minor role in my organisation & & & \\
\hline
\end{tabular}

Scores on a five point scale from $1=$ strongly disagree to $5=$ strongly agree; $*=$ negatively formulated question 
Table 10: T-test on the difference in (a) appreciation and (b) value between general managers and quality managers of the 2000 version in comparison to the 1994 version.

\begin{tabular}{|lcc|}
\hline a) Appreciation of aspects & Sig. (2-tailed) & $\begin{array}{c}\text { Mean Difference } \\
\text { General man. -/- } \\
\text { Quality man. }\end{array}$ \\
Customer orientation & 0.00 & -0.27 \\
Management behaviour & 0.00 & -0.31 \\
Employee involvement & n.s. & -0.07 \\
Process control & 0.02 & -0.24 \\
Improvement approach & 0.00 & -0.41 \\
Quality responsibility & n.s. & -0.03 \\
Quality manual & $n . s$. & 0.00 \\
Internal Communication & 0.04 & -0.16 \\
Relationship with suppliers & 0.00 & -0.23 \\
Service delivery & 0.00 & -0.22 \\
Management control & 0.00 & -0.35 \\
Training & 0.00 & -0.22 \\
Time taken to complete the certification & $n . s$. & -0.11 \\
process & & -0.23 \\
Cost of the certification process & 0.00 & -0.23 \\
Importance of the certification to customers & 0.01 & \\
(b) Value & & -0.16 \\
Assessment of value & & \\
\hline
\end{tabular}


Table 11: Factor analysis on the effects (effect 2000 version -/- effect 1994 version) of ISO 9000

\begin{tabular}{|c|c|c|c|c|}
\hline \\
\hline \multicolumn{5}{|l|}{ Rotated Component Matrix } \\
\hline variance explained: & $17 \%$ & $14 \%$ & $12 \%$ & $12 \%$ \\
\hline Management control & 0.75 & & & \\
\hline Leadership & 0.68 & & & \\
\hline Customer focus & 0.65 & & & \\
\hline Customer satisfaction & 0.58 & & & \\
\hline Continuous improvement & 0.52 & & & \\
\hline Employee satisfaction & 0.50 & & & \\
\hline Employee absence & & 0.67 & & \\
\hline Scrap in processes & & 0.63 & & \\
\hline Rework & & 0.60 & & \\
\hline Employee turnover & & 0.58 & & \\
\hline Teamwork & & 0.52 & & \\
\hline Efficiency of processes & & 0.50 & & \\
\hline Market share & & & 0.74 & \\
\hline Attraction of new customers & & & 0.68 & \\
\hline Customer loyalty/Repeat business & & & 0.67 & \\
\hline Brand/Image & & & . & \\
\hline Quality of products & & & & 0.83 \\
\hline Quality of service & & & & 0.69 \\
\hline Quality focus & & & & 0.50 \\
\hline Cronbach's alpha & 0.80 & 0.78 & 0.70 & 0.72 \\
\hline $\begin{array}{l}\text { Extraction Method: Principal Component A } \\
\text { Rotation converged in } 9 \text { iterations. } \\
\text { Kaiser-Meyer-Olkin Measure of Sampling } \\
\text { Square }=3553.55, \mathrm{df}=171 \text {, significance }=\end{array}$ & $\begin{array}{l}\text { s. Rotation } \mathrm{N} \\
\text { acy }=0.91 ; \mathrm{r}\end{array}$ & lod: Varimax & $\begin{array}{l}\text { th Kaiser No } \\
\text { nericity, App }\end{array}$ & x. Chi- \\
\hline
\end{tabular}


Table 12: T-test on the difference between general managers and quality managers in relation to the effects of ISO $9000(2000-/-1994)$

\begin{tabular}{|lcc|} 
& Sig. (2-tailed) & Mean \\
Difference \\
delta Q16 Quality philosophy & 0.00 & -0.45 \\
delta Q16 Operational aspects & n.s. & -0.05 \\
delta Q16 Market share/image & n.s. & 0.04 \\
delta Q16 Quality product/service/focus & 0.04 & -0.18 \\
\hline
\end{tabular}




\section{Publications in the ERIM Report Series Research* in Management}

\section{ERIM Research Program: "Organizing for Performance"}

2004

Learning And Governance In Inter-Firm Relations

Bart Nooteboom

ERS-2004-003-ORG

http://hdl.handle.net/1765/1122

Organisational Learning And Multinational Strategy

Bart Nooteboom

ERS-2004-004-ORG

$\underline{\text { http://hdl.handle.net/1765/1123 }}$

Density And Strength Of Ties In Innovation Networks: A Competence And Governance View

Bart Nooteboom and Victor A. Gilsing

ERS-2004-005-ORG

http://hdl.handle.net/1765/1124

Innovation, learning and cluster dynamics

Bart Nooteboom

ERS-2004-006-ORG

http://hdl.handle.net/1765/1125

Empirical Tests Of Optimal Cognitive Distance

Stefan Wuyts, Massimo G. Colombo, Shantanu Dutta, and Bart Nooteboom

ERS-2004-007-ORG

$\underline{\text { http://hdl.handle.net/1765/1126 }}$

Entrepreneurship in Transition: Searching for governance in China's new private sector

Barbara Krug and Hans Hendrischke ERS-2004-008-ORG

http://hdl.handle.net/1765/1128

Exploring Emotional Competence: Its effects on coping, social capital, and performance of salespeople Willem Verbeke, Frank Belschak and Richard P. Bagozzi

ERS-2004-014-ORG

http://hdl.handle.net/1765/1174

The Impact of Business Ownership Change on Employee Relations: Buy-outs in the UK and the Netherlands Hans Bruining, Paul Boselie, Mike Wright and Nicolas Bacon ERS-2004-021-ORG

$\underline{\text { http://hdl.handle.net/1765/1263 }}$

* A complete overview of the ERIM Report Series Research in Management: https://ep.eur.nl/handle/1765/1

ERIM Research Programs:

LIS Business Processes, Logistics and Information Systems

ORG Organizing for Performance

MKT Marketing

F\&A Finance and Accounting

STR Strategy and Entrepreneurship 
Towards a Dynamic (Schumpeterian) Welfare Economics

Wilfred Dolfsma

ERS-2004-026-ORG

http://hdl.handle.net/1765/1264

The Three-Step Test-Interview (TSTI): An observational instrument for pretesting self-completion questionnaires

Tony Hak, Kees van der Veer and Harrie Jansen

ERS-2004-029-ORG

http://hdl.handle.net/1765/1265

Measuring the Knowledge Base of an Economy in terms of Triple-Helix Relations among 'Technology, Organization, and Territory'

Loet Leydesdorff, Wilfred Dolfsma \& Gerben van der Panne

ERS-2004-034-ORG

http://hdl.handle.net/1765/1300

Paradoxes of Modernist Consumption - Reading Fashions

Wilfred Dolfsma

ERS-2004-035-ORG

http://hdl.handle.net/1765/1330

Some Economics of Digital Content

Wilfred Dolfsma

ERS-2004-036-ORG

http://hdl.handle.net/1765/1331

Learning Opportunities And Learning Behaviours Of Small Business Starters: Relations With Goal Achievement, Skill

Development, And Satisfaction

Marco van Gelderen, Lidewey van der Sluis \& Paul Jansen

ERS-2004-037-ORG

http://hdl.handle.net/1765/1429

The Process Of New Service Development - Issues Of Formalization And Appropriability

Wilfred Dolfsma

ERS-2004-051-ORG

http://hdl.handle.net/1765/1445

On And Off The Beaten Path: How Individuals Broker Knowledge Through Formal And Informal Networks

Rick Aalbers, Wilfred Dolfsma \& Otto Koppius

ERS-2004-066-LIS/ORG

http://hdl.handle.net/1765/1549

Governance Modes For Systemic Innovation. Service Development In Mobile Telecommunications

$J$. van den Ende and F. Jaspers

ERS-2004-067-ORG

http://hdl.handle.net/1765/1539

Human Resource Function Competencies In European Companies

Paul Boselie and Jaap Paauwe

ERS-2004-069-ORG

http://hdl.handle.net/1765/1451

Web-Based Organizing In Traditional Brick-And-Mortar Companies: The Impact On HR

Jaap Paauwe, Elaine Farndale and Roger Williams

ERS-2004-071-ORG

http://hdl.handle.net/1765/1609 
Longevity in services: the case of the Dutch warehousing companies 1600-2000

Hugo van Driel, Henk Volberda and Sjoerd Eikelboom

ERS-2004-072-STR/ORG

http://hdl.handle.net/1765/1571

Honing and Framing Ourselves (Extreme Subjectivity and Organizing)

Sławomir Magala

ERS-2004-076-ORG

http://hdl.handle.net/1765/1583

Cross-cultural compromises, multiculturalism and the actuality of unzipped Hofstede

Sławomir Magala

ERS-2004-078-ORG

http://hdl.handle.net/1765/1584

Perceptions about the ISO 9000 (2000) quality system standard revision and its value: The Dutch experience T. van der Wiele, J. Iwaarden, R. Williams and B. Dale

ERS-2004-081-ORG

Mystery shopping: A tool to develop insight into customer service provision

M. Hesselink, J. van Iwaarden and T. van der Wiele

ERS-2004-082-ORG

A transparent role of information systems within business processes: A case study

Menno Verboom, Jos van Iwaarden and Ton van der Wiele

ERS-2004-083-ORG 